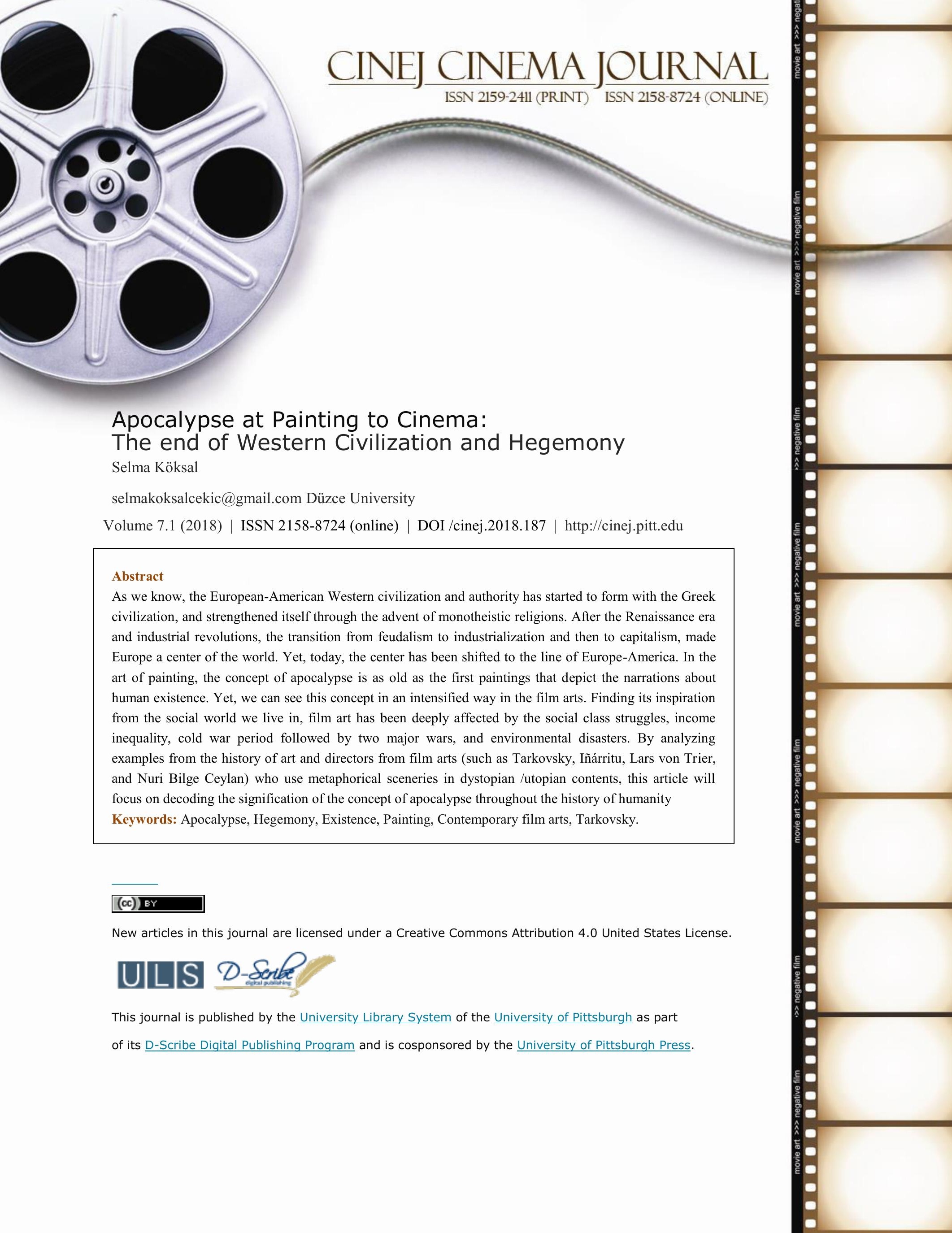




\section{Apocalypse at Painting to Cinema: \\ The end of Western Civilization and Hegemony}

\section{Selma Köksal}

\section{Andrei Tarkovsky and Apocalypse in his Films}

Tarkovsky is a unique director in the sense that he deals with the self-awareness and self-critique of humans, who turned their idyllic existence into hell. Tarkovsky appeals not only to those interested in cinema as an art form but also to those interested in poetry, philosophy, literature alike. He invites his audience to reflect on human existence. With this respects, he is an artist and thinker ahead of his time, our time, both visually poetic and thought-provoking.

The central theme of Tarkovsky's cinema is the question of the "Destiny of Human Beings". Tarkovsky does not deal with this question as a dead-end. On the contrary, we are invited to a life-long process of thinking reflecting, and into a universe of meaning. The "dystopic universe" in his films does not lead to endings without hope but entice us towards "utopia". The first film of Tarkovsky's career "The Childhood of Ivan" is about the worst nightmare of humanity: "war". War is an absurdity that ravishes the innocent and naive world of a child. We observe Ivan watching a reproduction of Dürer's "the four horsemen of apocalypse", he saw a German motorized soldier as resembling one of the horsemen. Apocalypse on both personal and general planes is a recurring theme for Tarkovsky.

In Tarkovsky's second film "Adrei Rublev", an artist-monk is commissioned to paint the "Day of Apocalypse", mentioned in the Bible. He is unable to do, so far, he does not want to frighten people. Tarkovsky leads us to the center of the question of theology; as a tool for enhancing power. The films shows us that the passion for wealth, power and the political systems established to this end lead humanity to war; that is the true apocalypse. 


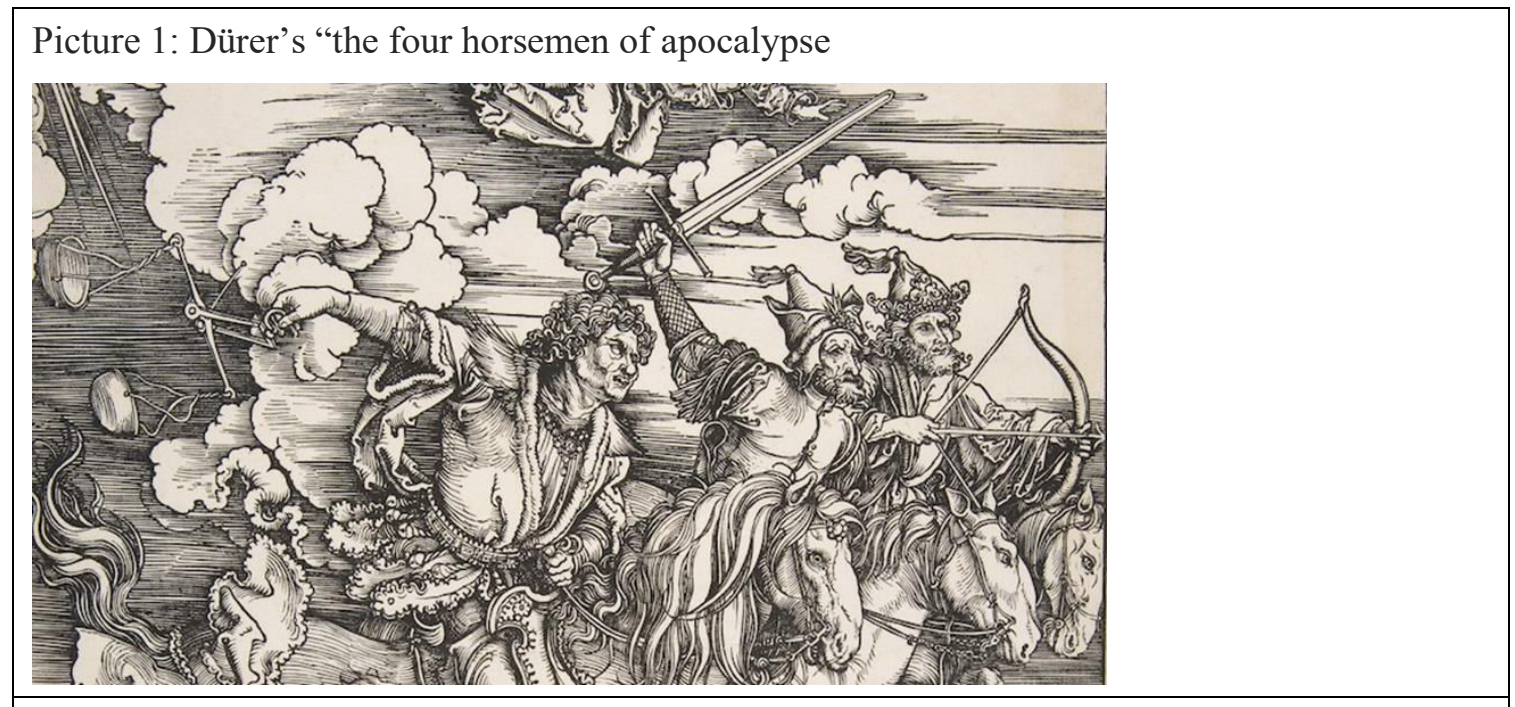

Picture 2: A scene from film "Andrei Rublev", which looks like a Bruegel painting

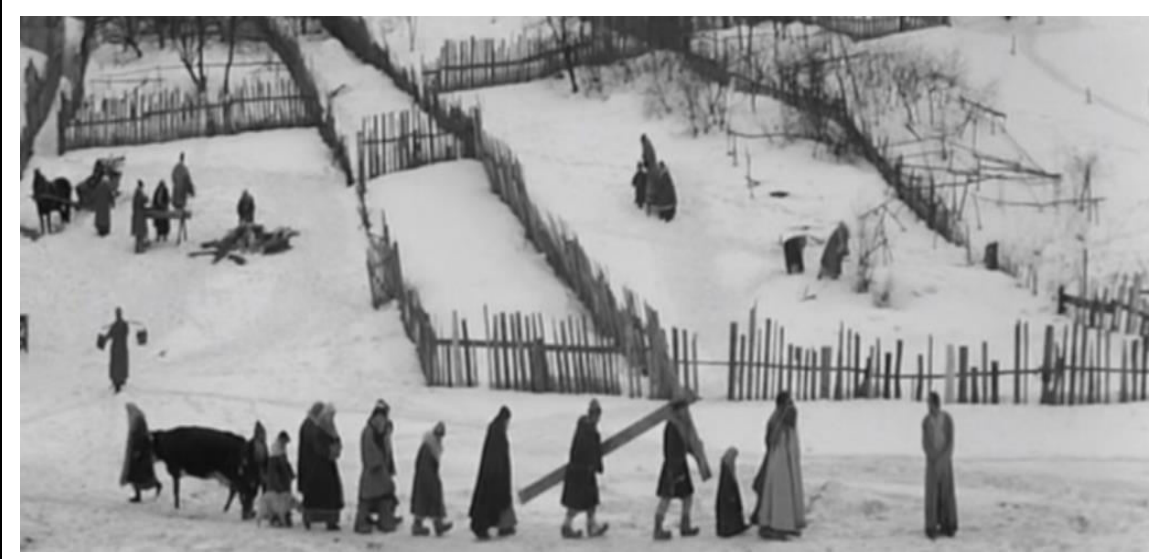

Picture 3: The Russian Cavalry scene in Andrei Rublev is reminiscent of Bruegel's The Road to Calvary

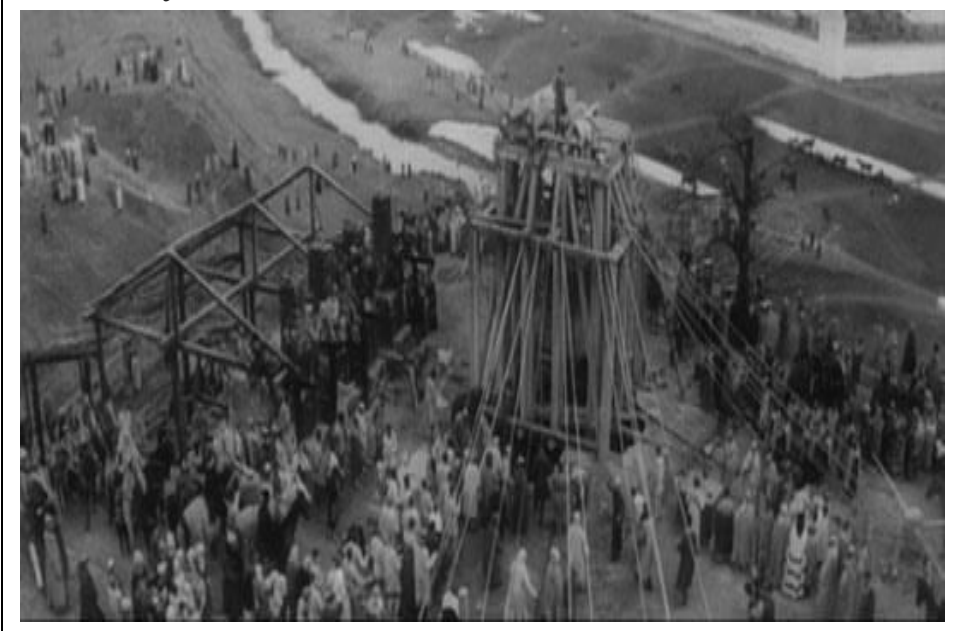


Andrei escapes Pagan village and emerges by river bank. This scene refers to Alexander Ivanov's The appearance of Christ to the people - Alexandre Ivanov and Ivan Kramskoy Christ in the Desert.

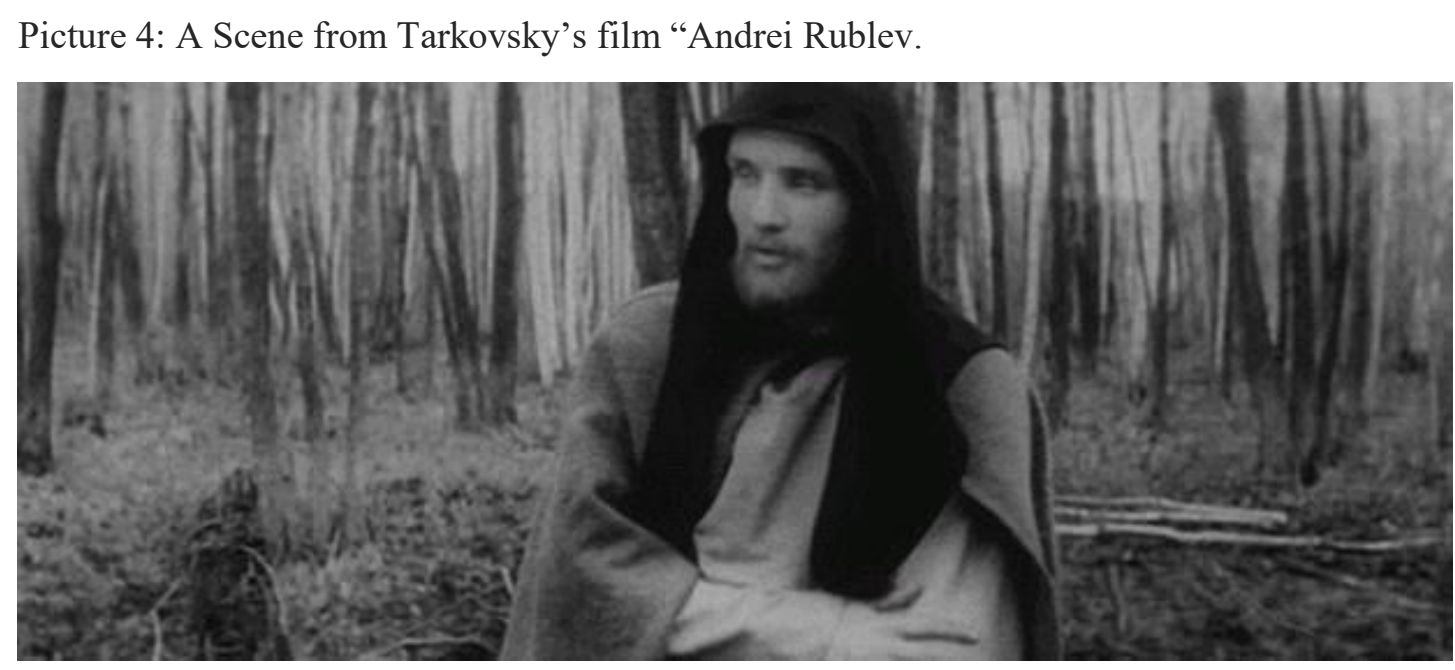

Picture 5: Alexandre İvanov Kramskoy "Christ in the Desert".

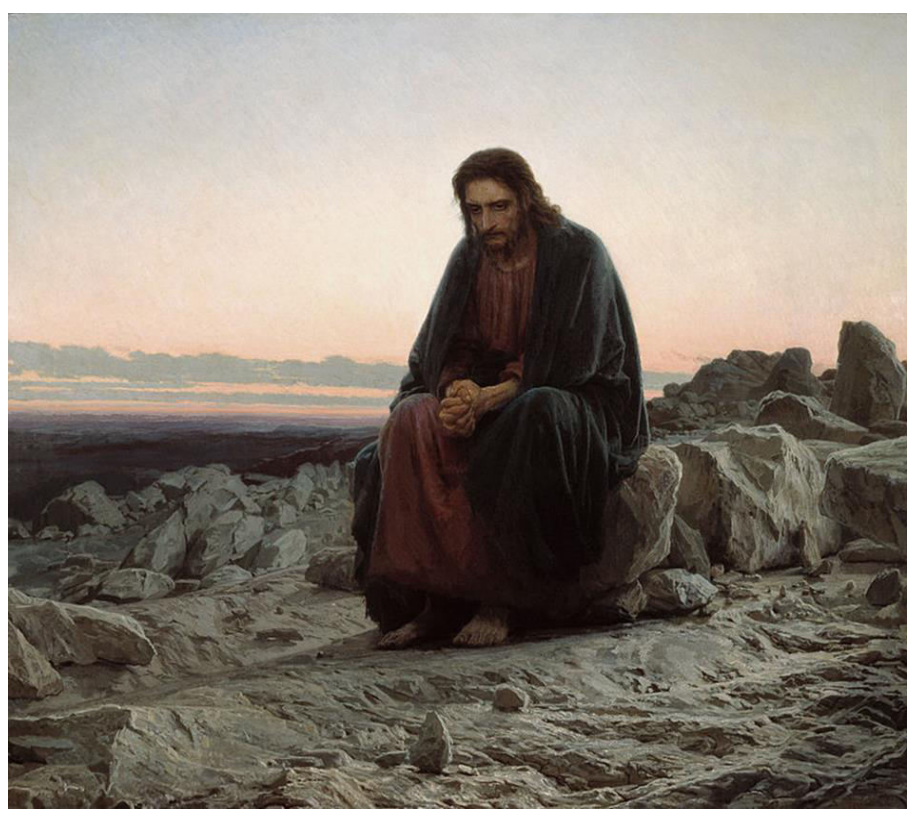

Tarkovsky's first philosophical science-fiction work "Solaris" deals with scientists. Scientists in the space station of Solaris have been going mad for unknown reasons. The 
protagonist of the film, Kevin, is warned by his father before his journey of investigation. The father states that sending people like Kevin into the space is too dangerous and says; "everything these is fragile, all too fragile". Later in the film, we realize that this is the space within us, the place of facing our own conscience," like the ocean of inside", or "universe of our insides". Solaris is the testimony of Tarkovsky for facing the space within. Kevin's feelings of guilt are about his wife Hari who committed suicide ten years ago. Hari's copy states at Bruegel's Hunters of Snow in the library, and hears the dogs and the birds as if they came alive. We will return to this points in discussing Trier and discussing his way of thinking about apocalypse and about the position of human being. In his second science-fiction work," Stalker", Tarkovsky, goes deeper into the topic. This time, the protagonist is a physician, a writer and the 'stalker' who takes them to the 'Zone'. We witness that science and art become immoral and contribute creating the hell on the Earth. We observe that the civilization created by the scientists and the artists is devoid of peace and happiness, and is instead ridden with anxiety and pride. Stalker talks about the Zone as 'home'. The Zone includes a chamber that emerged after a meteor impact 20 years ago, and that fulfills the innermost desires of a human being. The professor believes that the chamber can be misused by politicians and like. He takes out a bomb from his bag and argues that the chamber to be destroyed. Stalker stops him and prevents the destruction of hope. Upon his return home, he complains that people have lost faith. Stalker and the following two films: Nostalgia and Sacrifice are closely related. All three focus on a central theme of Tarkovsky: an approaching apocalypse and the struggle to prevent it. Post-industrial aesthetics of Stalker depicts the world as rotten, broken, old, and in ruins. The camera's movement across the shallow water exposes various military and industrial debris. 
For a moment we see the details of "Grand Altar" by Van Eyck brothers, surrounded by seaweeds, and old coins.

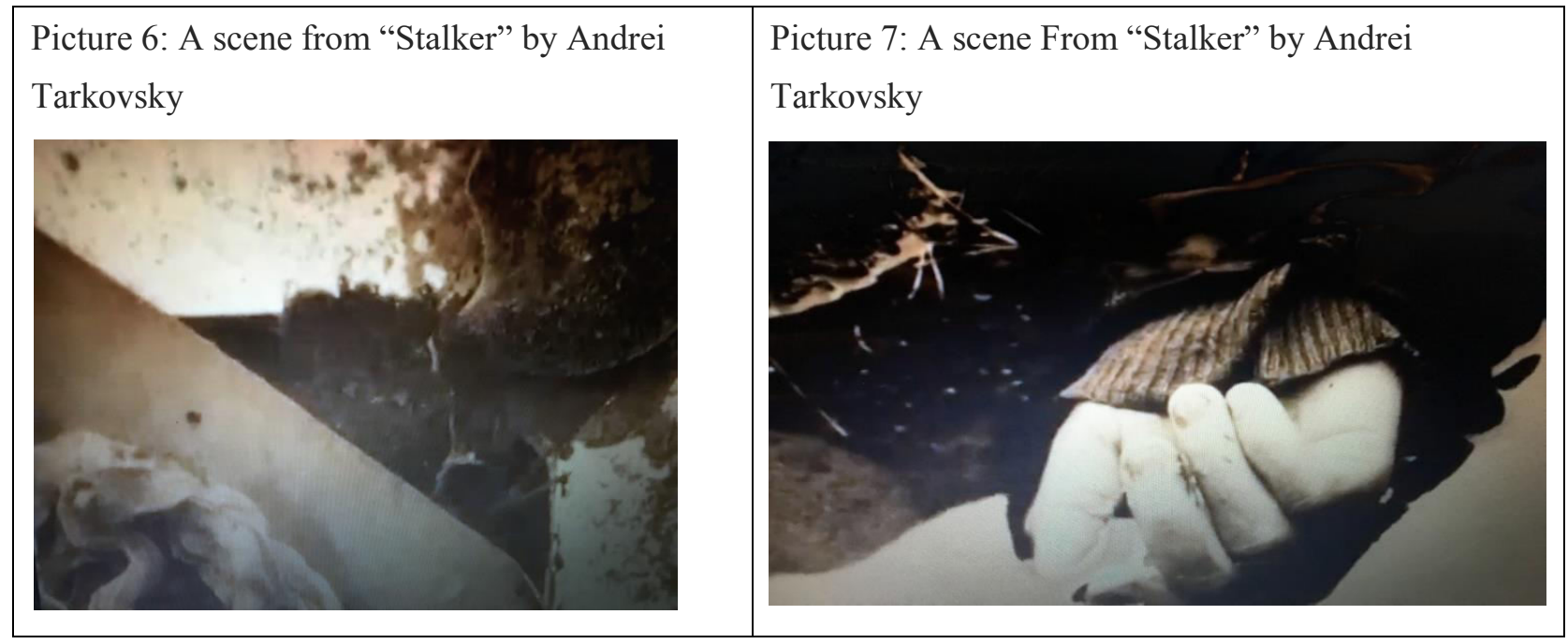

Yearning for a better world, Tarkovsky realizes that it requires massive effort and the prospects are not good. The spiritually barren lands of the film are also barren because of pollution. The water is mostly dirty and still. The film is both a register of Tarkovsky's inner words and feelings, but it also reaches out to see whether a better world is possible. We can define it as the Picture of the soul after confession.

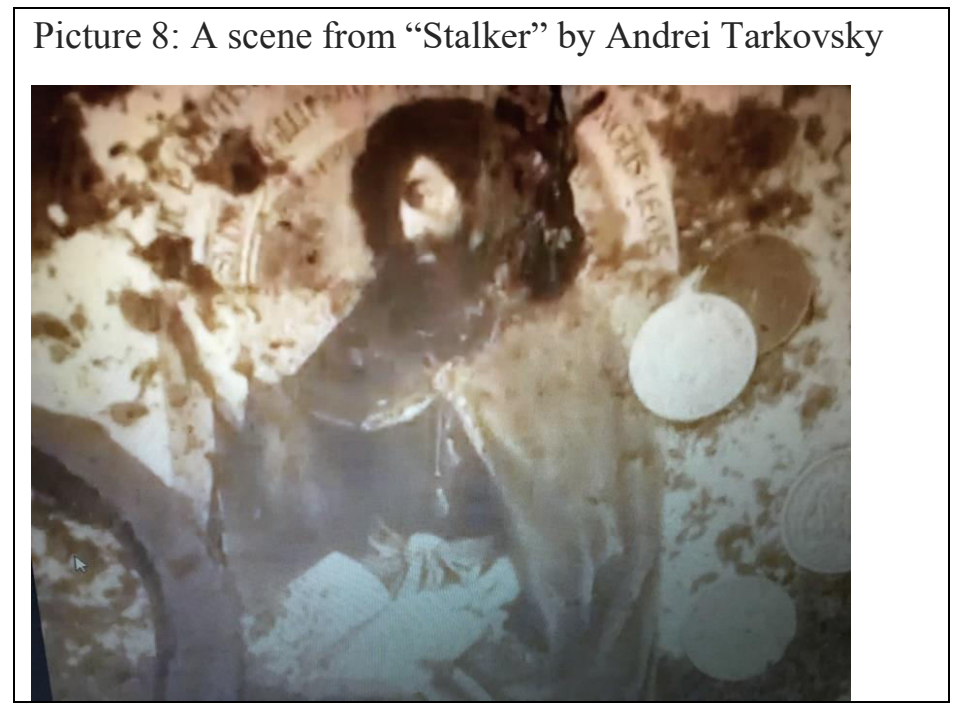




\section{Lars Trier; as a European Director}

Apocalypse is dealt with a multi-layered philosophical approach by Tarkovsky. Among other directors dealing with the theme is Lars von Trier. Trier defines himself as a 'European director', and follows an interesting chronology in his films: Europe trilogy, America trilogy, Golden Heart trilogy, and Depression trilogy. Trier expresses his admiration for Tarkovsky on several occasions, and made various references through visual metaphors. Yet, Trier defines his concept of civilization as Euro-America. In Trier's films, the world is limited to the EuroAmerican civilization, and the hegemony of this civilization creates political claustrophobia. It is not possible to give an exhaustive discussion of Trier's all films. So, I will focus on especially "Melancholia", which is a part of Trier's Depression trilogy.

\section{Melancholia}

The film Melancholia is made up of two parts; Justine and Claire. The two parts are symbolized by two women in depression. The first part is 'Justine'. We see the newly-weds Justine and Michael in a grand limousine. The couple enter the wedding venue, a large mansion, belated. The limousine cannot pass through the narrow roads leading to the mansion. From the very start, the lack of harmony between luxury and nature's paths is underlined. Justine's sister Claire, and her husband John as the host of the wedding, and they are upset and angry because of their delate. Even though they are already late, Justine, spoiled with happiness, prefers to visit her horse Abraham whom she misses. Afterwards, they join the wedding crowd. We can define the guests as bourgeoisie, posh and loveless.

During the wedding, Justine's father steels the silver, arrogates the servant, and behaves aggressively towards his ex-wife. During the wedding, Justine's boss pressures her regarding to 
a new advertising campaign, Justine's mother locks herself-up in a room in a state of loneliness and depression. The father is weak, selfish and ego-centric, while the mother is strong, harsh, loveless, and equally self-centered. These parental figures hint Justine's depressive personality. The rich metaphoric worlds of the films in indicated by the name Justine. Justine is the main character in Marquis de Sade's book “Justine, or the Misfortunes of Virtue”. In the book; naive and virtuous Justine is raped and abused by the clergy and merchants. Justine's sister lecture her in bourgeoisie attitude on morality and virtue.

Justine is unable to enjoy the loving and benevolent attitude of her husband. Instead of joining the cake-cutting ceremony, she isolates herself in a room in a depressive mood. Justine cannot bear the hypocritical joyousness of the weeding for long. Her wedding has turned into a deadlock, and became unbearable. She feels alone in a fake and unloving world. This drives her further into melancholy and avenges this satiation at the wedding by engaging sexual intercourse with her assistant in the garden. Trier attempts to justify Justine's melancholy, using figures in the art, science and philosophy world that he takes seriously. Under immense emotional distress, Justine locks herself up in the library room. She throws a painting of Kazimir Malevich on the floor. The 1916 painting of Malevich is influenced by 'suprematism', disregards optic vision in favor of abstract and constructivist move away from nature. She replaces this Picture with those she finds meaningful. Here are the pictures she selects: Pieter Bruegel's landscape 'Hunters in Snow' Bruegel's “The Land of Cockaigne”, 1567, where he ironically depicts monastery life and praises pleasure and dreaming. Caravaggio is a leading figure of baroque, and is known for depressive paintings and a sentimental and colorful approach to reality. 


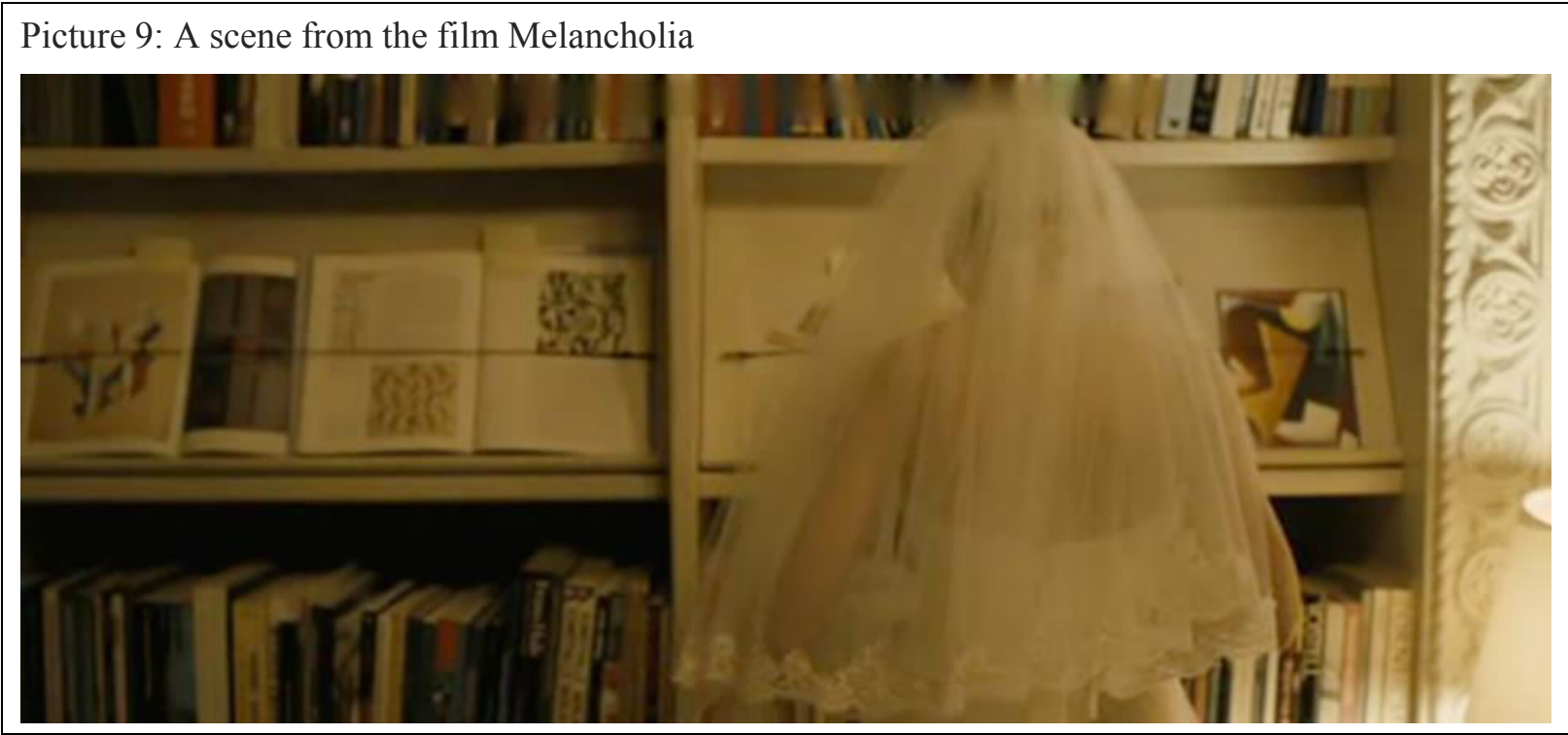

Picture 10: Pieter Bruegel's landscape 'Hunters in Snow'

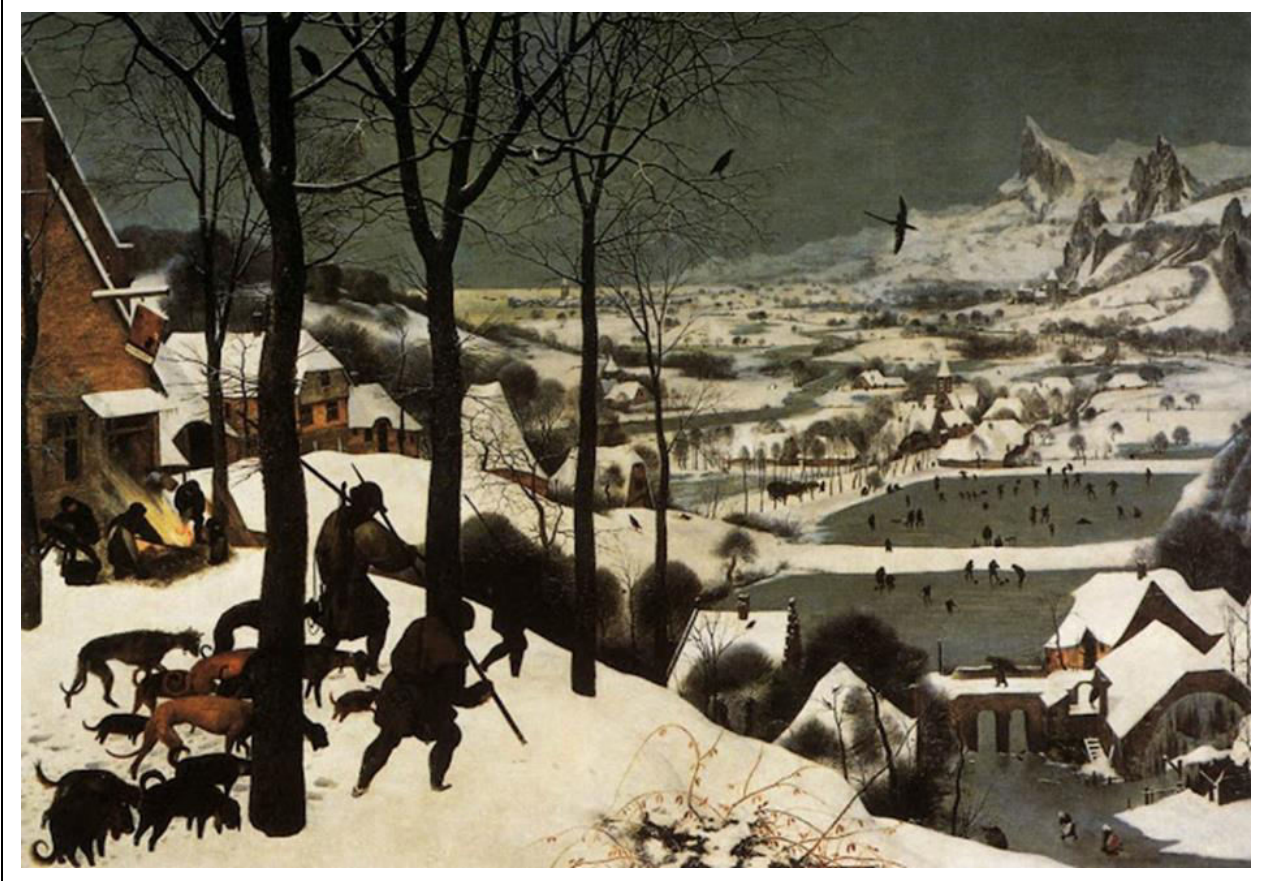


Millais's images are referred to by Trier also his films, Dogville and Antichrist. Ophelia is inspired by Shakespeare's "Hamlet", and depicts Ophelia who is thrown into depression and commits suicide on her wedding day.

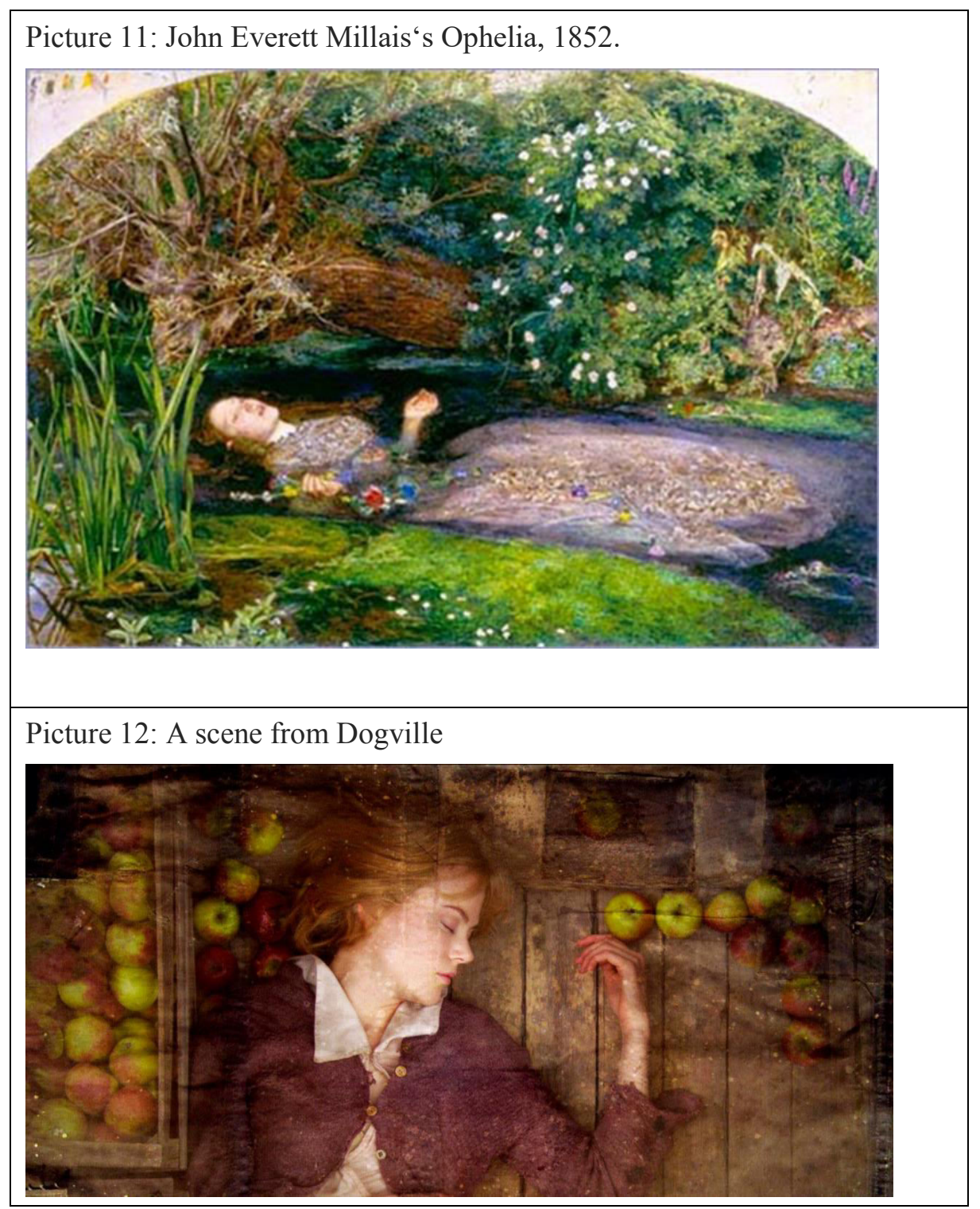




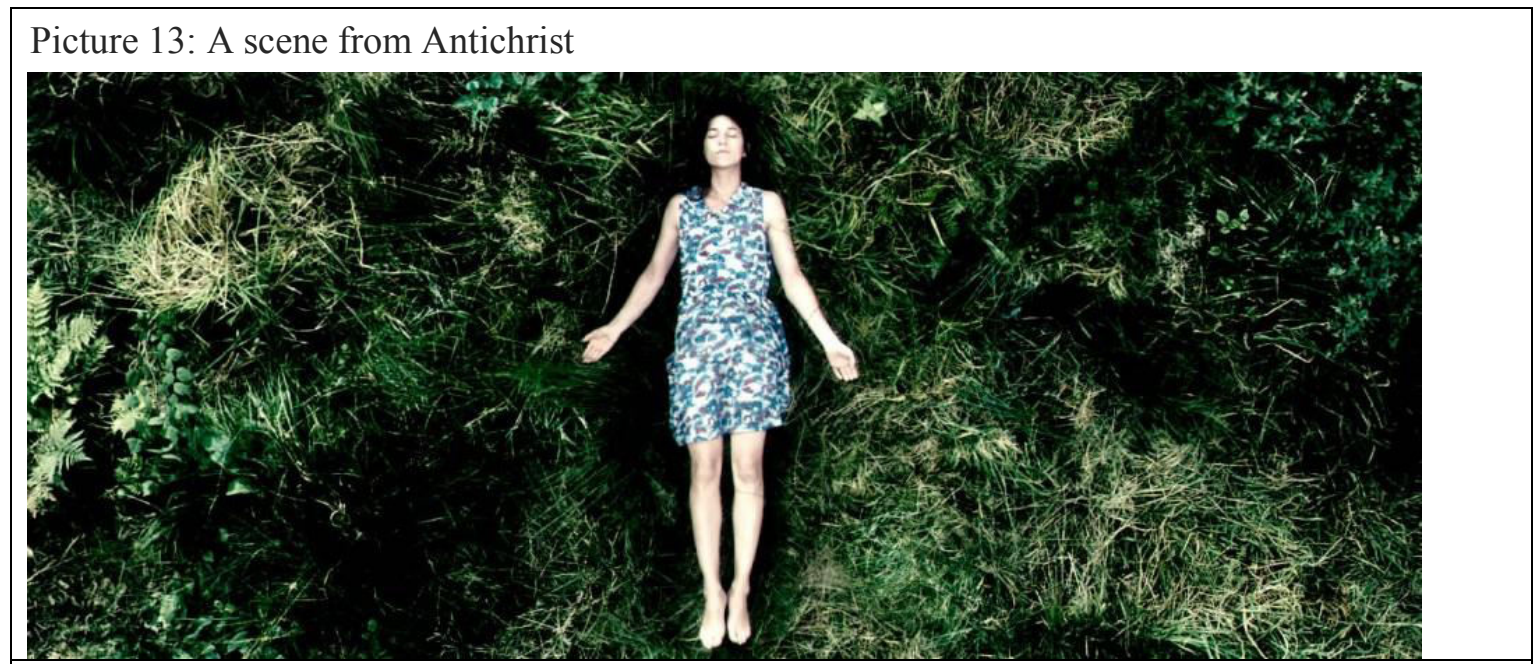

Picture 14: A scene from Melancholia

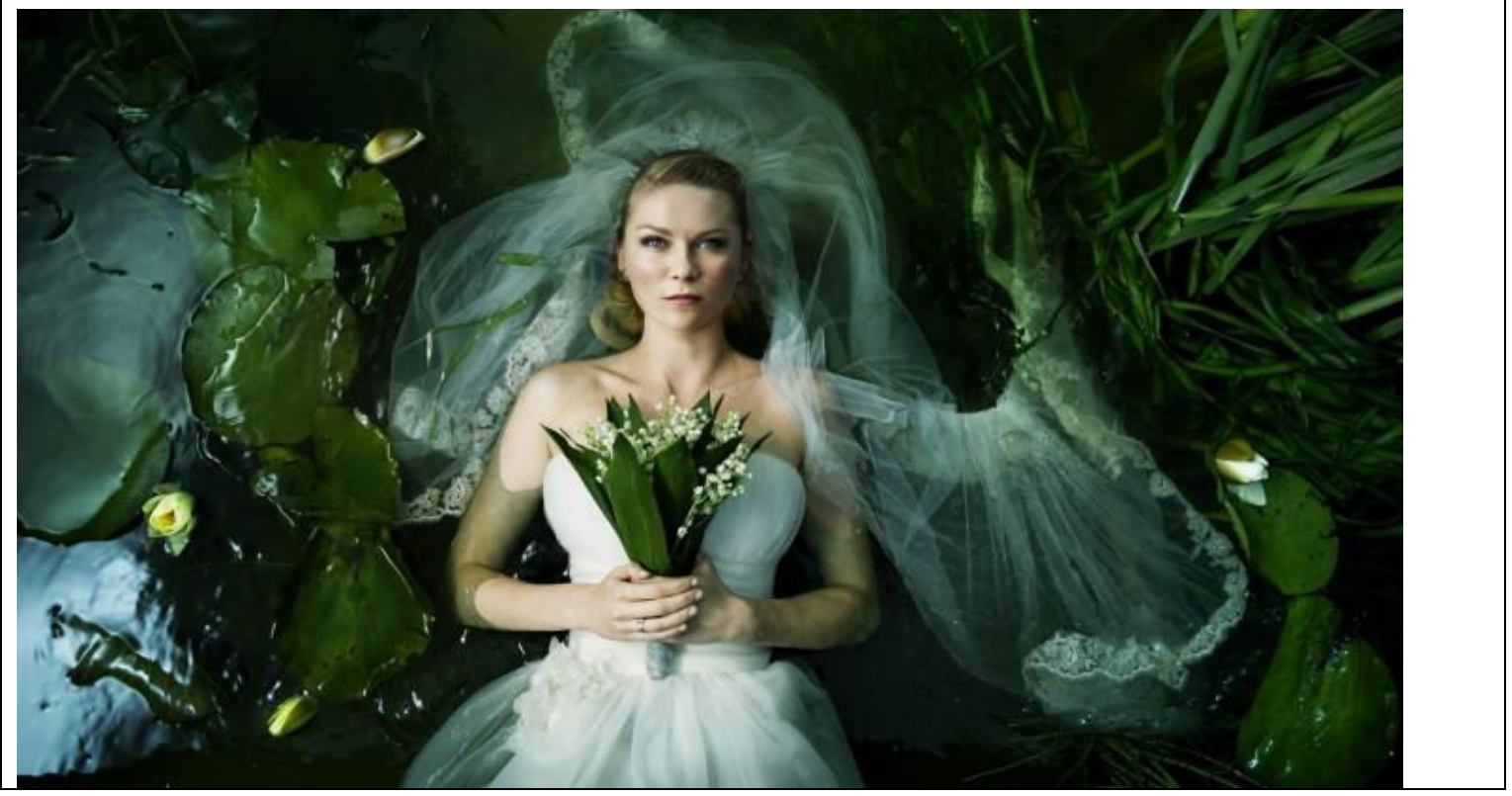

Using close-ups, Trier approaches Justine's melancholic view of life, just like the painters of these Works. This can also be read as a critique of hollow intellectualism widespread among the bourgeoisie after the industrial revolution in the 19th century. Justine's world is increasingly filled with darkness and solitude, and she is abandoned by her husband, father, mother and the wedding guests. Justine goes for a horse ride with her sister in the morning. Justine notes that the star of Antares, which is the brightest star in the Capricorn 
constellation is no longer visible. Justine had noticed the star the previous day on their way to the wedding.

The second part of the film is named "Claire". For Trier, this marks the fact that depressive dynamics are now over for Justine and beginning for Claire. Claire is overwhelmed by the anxiety of whether planed Melancholia will hire the world. Her husband makes observations using his telescope and assures Claire that the planet will bypass the earth according to his calculations. For the husband, this is an astral fiesta to be enjoyed, but Claire gets all the more anxious by reading apocalyptic predictions on the internet. Horses in the barn become restless and Melancholia became all the more visible in the sky. Claire spends the night anxiously staring at the bright light of Melancholia, whereas Justin wants to be part of its apocalyptic beauty. She bathes naked in its light. For Justine, Melancholia is not just a beautiful sight, it also signals the end of the evil dominating the world. Another significant moment is when Abraham, the horse, refuses to step beyond the bridge, symbolizing a limit. This is a central metaphor since Abraham (also the name is significant), cannot leave this world, which is in my view is the Euro-American world. This sort of political claustrophobia is internalized in Trier films.

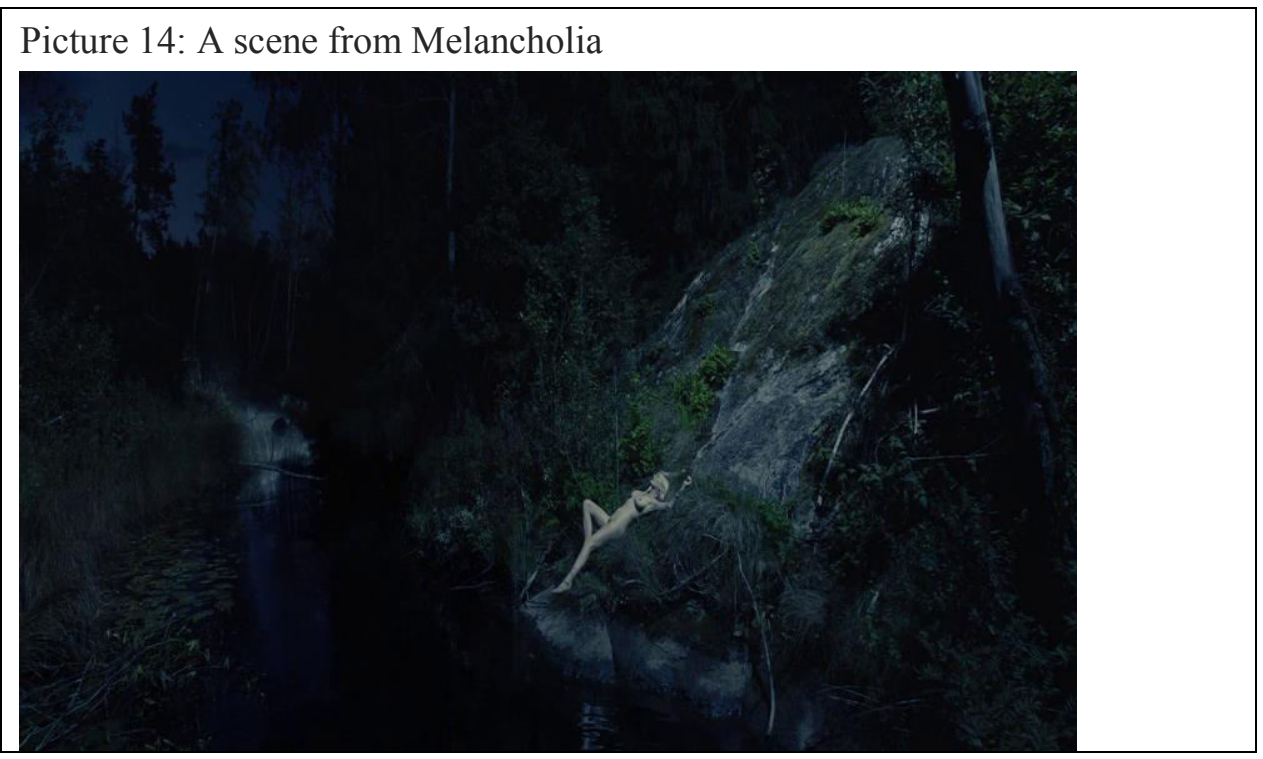


The second part of the film; "depression" is handed over to Justine's sister Claire. Still, this is a belated sorrow. It is no longer possible to prevent the approaching disaster. Claire loses her rational properness and starts suffering. In contrast, Cassandra Justine, had already felt the inevitableness of the disaster and fallen into melancholia. In stark contrast with Justine's deeper and seasoned senses, Claire, with her Western, Euro-American outlook, is belated in her senses. It is, of course, to emphasize the gender of both characters. In Trier's world, men are always underdeveloped and selfish characters often depicted in their roles of husbands, fathers or employers. In this sense, they are in the background. John, tries to calm down Claire and asks her to disregard what she has been reading on the approaching planet. However, he is also secretly engaged in making preparations. Their son, meanwhile, makes a simple instrument of observation using wires. Claire uses this instrument as a tool for her own observations in the middle of an atmosphere riddled with her husband's control over her sources of information, and the growing anxiety of 'not knowing' in their isolated mansion. It is needless to emphasize that science and technology is a tool for Euro-American hegemony on nature. For Trier, science and technology employed in this way can never dominate nature.

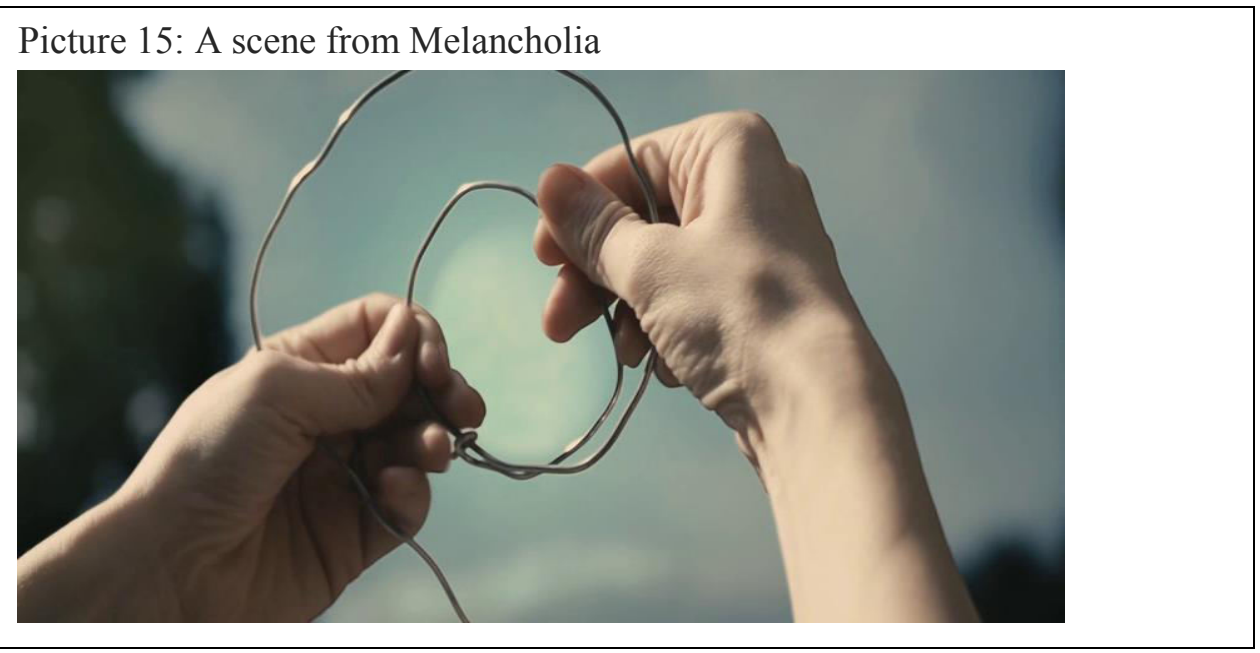


Claire is desperate enough to consider committing suicide. The servant misses work on this very last day. Justine reacts to Claire's anxiety by stating that the world is about to come to an end because it is evil. For Trier, human beings are evil and should not exist: they are a menace to the world, and even to the entire universe.

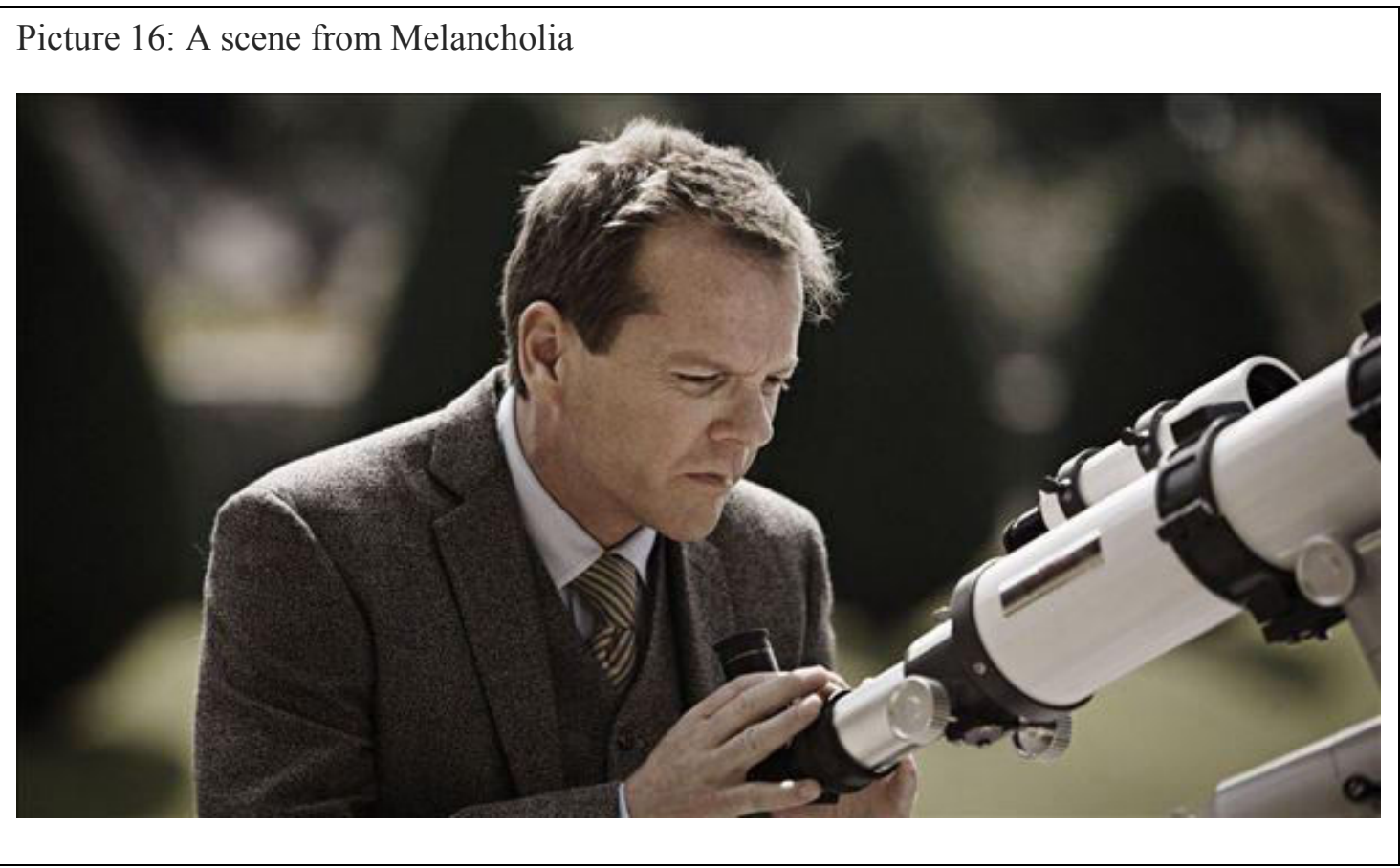

John's most recent calculations confirm the coming disaster. He secretly commits suicide using Claire's sleeping pills. Claire and her son will now face the apocalypse without John. Claire is in a desperate state. She turns to Justine and says that she wishes to spend these last minutes together, drinking wine and listening to Beethoven's $9^{\text {th }}$ symphony. Justine refuses the idea, and states that it is meaningless. Justine wants to sooth the boy's anxiety by building a 'magic cave' together. We can argue that Trier's choice is an allegory to "Plato's cave". Human beings are responsible for creating a hypocritical and evil world. It is now time to come out of the cave, and seek the truth, true meaning, and what is truly good for humanity. In Plato's metaphor, those who discover the truth are supposed to enlighten their fellow human 
beings. For Plate, the meaning of life is not in the search for truth, but in the act of sharing it with those still in the cave; that is, when the truth is crystallized in collective consciousness.

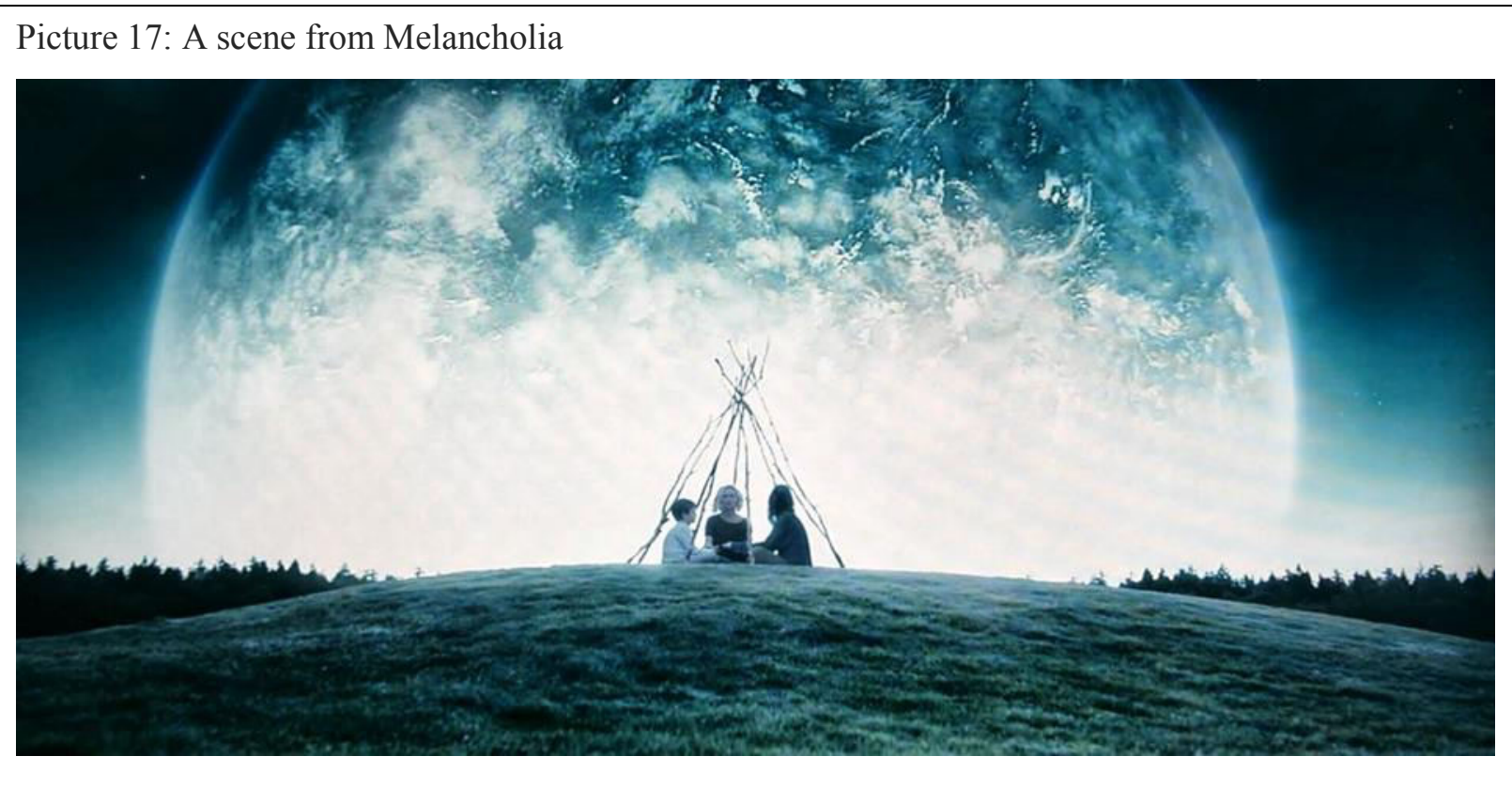

Another interpretation of the scene emphasizes the resemblance with an Indian tent. Indians created a civilization in harmony with the planet and the universe but were brutally annihilated by the military-technological might of the Euro-American civilization. Perhaps the final scenes of the film are a dim light of hope in Trier's otherwise dark and grim world. For we need some light even to realize that we are in darkness. Trier's critique of the modern bourgeoisie civilization consists of several elements. One of them is his critique of scientific reason and technology. In his film Antichrist, his expertise in psychology cannot prevent his wife's drift towards madness. In Epidemic, science is part of the problem. The savior-scientist is the very person spreading the virus. Producing the anti-virus is compared to the Signal commercial. In Melancholia, physics and astronomy are powerless to foresee the approaching disaster. A simple instrument held against the chest and prophecy prove to be much more effective. 


\section{Cassandra, Ophelia, Hamlet and Wild Strawberries}

In the film "Wild Strawberries", Bergman examines love, marriage and the relations between men and women. The film shows that deeper feelings and love is not compatible with the distance and norms. In the "Melancholia" by Trier, the length and the significance of the wedding testifies to the fact that private sphere dominates public sphere and its central role in the system. Nuclear family is at the heart of the capitalist system. "Melancholy" makes strong references to Bergman's film "Wild Strawberries". First; Justine's husband wants to give her a picture of the "wild strawberries orchard". Justine is too preoccupied with her problems to appreciate the gift. In the same film, we noticed wild Strawberries as a second time when it is snowing on Justine and Claire. In that scene they are picking wild strawberries. "Wild Strawberries" is a central metaphor in Bergman film and Tries seemingly shows us the alienation and distance between two sisters with wild strawberries. In that specific scene, Trier also shows us the closest moment between these two women. Justine and Claire are harmonious in the scene, even though they are opposites throughout the film. This is an interesting scene where we perceive what both of them sense and feel. So, where does the snow come from? I believe this is the snow of Bruegel.

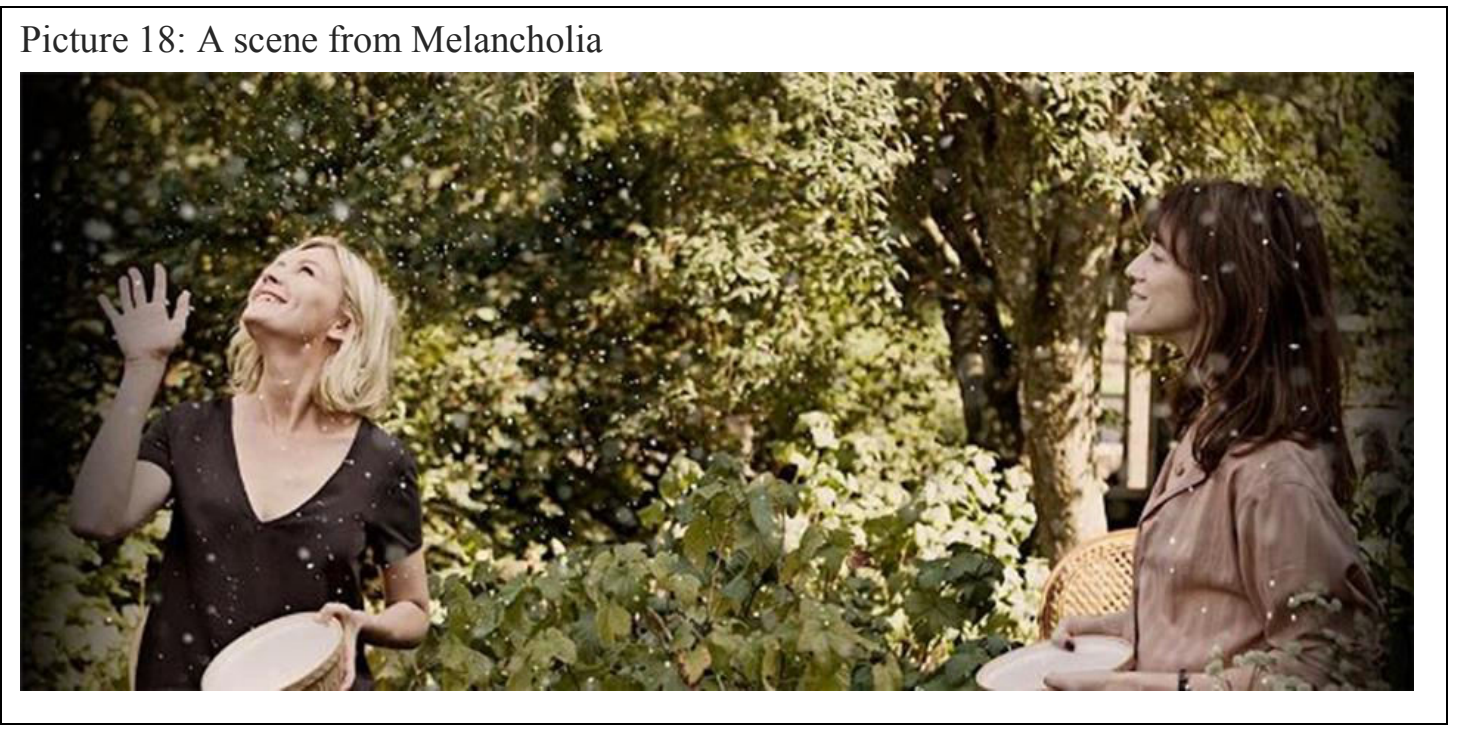


In Tarkovsky's Solaris, the neuron-copy of Kevin's wife Hari, who deceased 10 years ago, looks at Bruegel's picture "Hunters in Snow" in a space station. She hears some voice as if coming from picture such as the dogs and the birds. It is as if life on earth comes to life in the inner world of the neuron-copy, and she starts to feel. This is Trier's response to Tarkovsky's question in Solaris. The neuron-copy feels more vividly than a human being, showing the loss of balance between humans and the nature and their failure to grasp the meaning of life. It snows in the end; the nature avenges human arrogance. Bruegel's snow falls softly on Claire and Justine. Both women accept the end with romantic acceptance. Bruegel is a master of nonreligious painting. He paints the blues of the fall and the winter. As argued by art historian Venturi, Bruegel-- especially in his depictions of rural life-- expresses the simplicity of life beyond ideals and the day-to-day dealings of ordinary people. Yet the Renaissance does not claim melancholy in rural life alone. Trier's fill refer to Brueghel, Caravaggio, and Millais, but not to Leonardo Da Vinci or Michelangelo, even though they too praise melancholia. This is a meaningful decision since melancholia is also breed by the supremacy of religion and science. Other powerful images used in the film are as follows: In prologue, or the pre-generic, Justine walks in her wedding dress, and she is embraced and pulled back by tree roots as if they identify with her. Similarly, Claire is pulled back by the earth, leaving deep foot prints on the ground. A similar scene can be found in Antichrist. She is pulled back by the ground and her feet burn. Trier frequently identifies women with the nature and takes men as the symbol of Western civilization. Nonetheless, women's identification with nature is frightening and ridden with danger. It is shown as an uninhibited and mad revolt against reason. 
Justine's scene with lightning in her hands as well refers to Michelangelo's 'Creation'. Life given by God is given back by Justine. She is calm and in harmony. Relays life into the skies as if this is supposed to happen, for humanity could not live up to it.

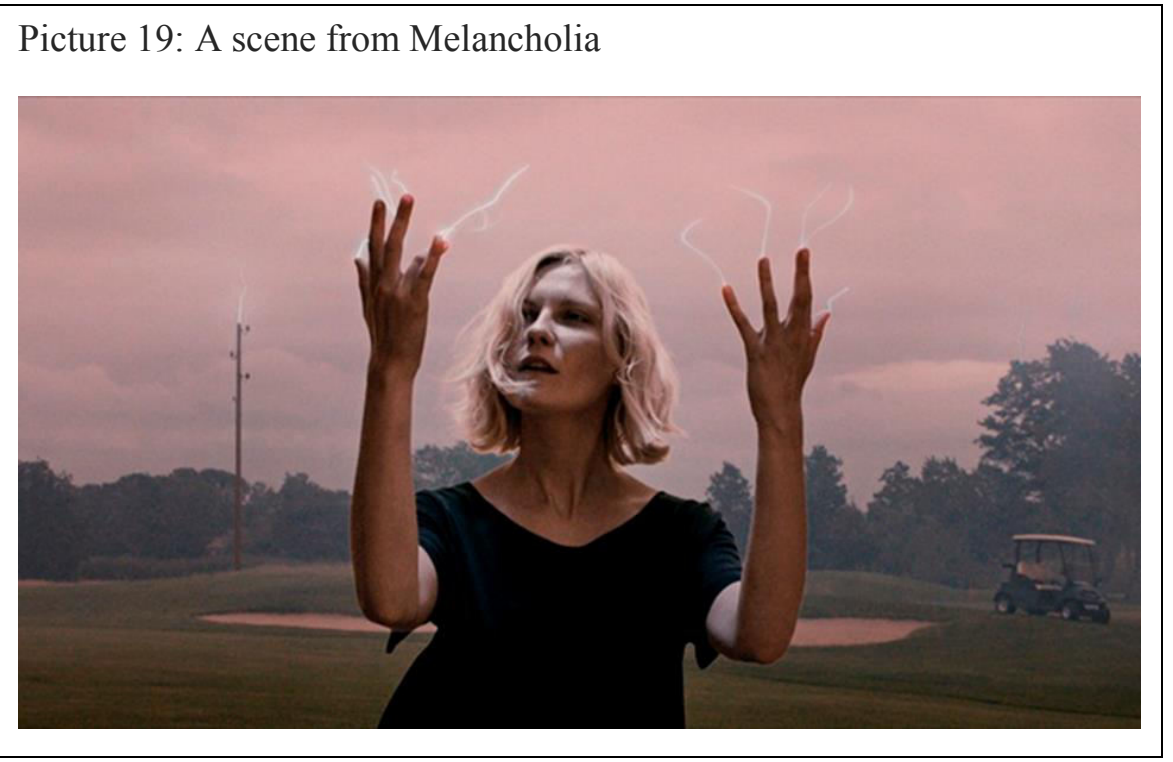

We also encounter the image of the burning bush twice in the film. First, the bush in the garden catches fire during wedding celebrations. Second, Claire sees bushes through the window during her hours of depression.

Relays life into the skies as if this is supposed to happen, for humanity could not live up to it. Melancholia's references to well-known narratives, Trier's choice of paintings as well as his reference to Tarkovsky mark one thing: human beings are in discord with their own existence and the universe, and are heading to an apocalypse of their own making.

However, in Tarkovsky's 'Nostalgia”, 'holy madman' Domenica calls out to people before he burns himself and invites them to 'create a new way of life and a new world'. Again, in the film "Sacrifice" (Offret) which is in a way Tarkovsky's will, Alexander says the following words: 'Human beings have destroyed the nature, and established a world dominated by fear and power. There is a frightening discord between our material and spiritual development. Our civilization is based on sin or things we do not need'. Alexander is prepared 
to pay the price for a nuclear disaster that will annihilate the world. He prays and says that he will sacrifice everything if God gives their lives back. He will burn his house, will his little son Adam, and will never speak again. "Sacrifice" (Offret) is the last film of Tarkovsky, made in exile and dedicated to his son. In contrast, Trier gives us a closed ending in Melancholia, just as he does in his other films. He argues that 'the world should end together with evil people and evil civilization on it. This is a discourse full of condescension and without hope or utopia. No need to say that it is also an extremely rational Euro-American discourse.

\section{BIBLIOGRAPHY}

Başoğul, R. Melancholia, http://www.rehabasogul.com/2011/10/22/melancholia-melankolilarsvon-trier-sinema-film-elestiri-analiz/.

Cündioğlu, D. Melancholia, http://ducanecundioglusimurggrubu.blogspot.com.tr/ 2012/09/melancholia.html\#!/2012/09/melancholia.html.

De Sade, M. (2009), Erdemle Kırbaçlanan Kadın çeviri: Yaşar İlksavaş, Oğlak Yayınları

Denny, D. (2007) “Signifying Grace: A Reading of Lars Von Trier's Dogville”, Žižek and Cinema - IJŽS, Vol 1, No: 3, 2007.

Jan Lumholdt (2003), Lars Von Trier: Interviews, Mississippi: University Press of Mississippi. Lars von Trier: Interviews (Conversations with Filmmakers Series) June 16, 2003

Greenberg, E. U. (2008) "The Holocaust Repressed: Memory and the Subconscious in Lars Von Trier Europa", Film and History: An Interdisciplinary Journal of Film and Television Studies, No: 38 .

Hjort, M. (2003) “The Problem with Provocation: On Lars von Trier, Enfant Terrible of Danish Art Film”, Kinema, http://www.kinema.uwaterloo.ca/article.php?id=492\&feature. 
Koutsourakis, A. (2013) "The Persistence of Dialectics or the Desire for History in Lars von http://www.academia.edu/4740354/Politics_as_Form_in_Lars_von_Trier_A_Post-

Brechtian_Reading_New_York_Bloomsbury_2013_

Maskowki, M. (2007)“The Evil of Modernity: Joseph Conrad's Heart of Darkness and Francis Ford Coppola’s Apocalypse Now”, Yearbook of Conrad Studies, Vol. 3.

Sean, M. (2013) Andrey Tarkovsky, çeviren: Irmak Yavlal, İstanbul: Kalkedon Yayınları.

Simons, J. (2015) “Anti-Christ: Tragedy, Farce or Game?”, Film-Philosophy, No: 19.

Simons, J. (2007) Playing the Waves: Lars von Trier's Game Cinema, Amsterdam: Amsterdam University Press.

Tuğcu, A. (13 Kasım 2012) “Lars von Trier Dosyası”, Ekşi Sinema, http://eksisinema.com/larsvon-trier-dosyasi/.

Von Trier, L. (2015) Sinema Tutkusu, (der.) Jan Lumholdt, çeviri: Selim Özgül, İstanbul: Agora Kitaplı̆̆ 